\title{
Television and Material Culture: Mediating the Temporal and Consumerist Practices in Pre-liberalised Kerala
}

\author{
Benita Acca Benjamin \\ Research Scholar, Institute of English, Kerala University. Email: benitabenjamin47@gmail.com
}

\begin{abstract}
The introduction of television in Kerala was an event marked by the encounter between spatial practices, discursive structures and visual paradigms. As a result, it becomes important to contextualise television's presence in Kerala in the socio-economic conditions that defined the region in and around the time when television was introduced. This would provide some seminal cues about the mutual imbrications between television and its politico-discursive context. The present paper tries to look into the ways in which television fashioned new spatio-temporal practices and embodied various consumerist tendencies in pre-liberalised Kerala to argue that television is an artifact grounded in the region's cultural values and material aspirations. The first section looks at how television-viewing and the socialities formed around the act were 'timed' by television. In the second section, the paper studies the popular advertising strategies employed to market television as a 'tamed' object that is representative of the consumerist aspirations that defined the region.
\end{abstract}

Keywords: Television, Material Culture, Temporalities of television, Consumerist aspirations

The material history of things has emerged as a field of enquiry that actively understands the embeddedness of objects within specific spatio-temporal contexts, bringing in its wake a turn towards the field of microhistory (Coltman, 2017). The history of television's domestication and the modernisation that it inaugurated in Kerala reveals the curious entanglements between the social and economic spheres that enabled the fraught mediations that it initiated between ideas and spaces, influencing the collective attitudes and private aspirations of the people. In this context, television warrants a discussion as it is not only a communicational tool but also a repository of social relations. Hence, the present paper attempts to understand the co-constitutive relation of television with the larger social, discursive and temporal structures, aiding its simultaneous existence as a material commodity and cultural artifact in and around the time when television was introduced in pre-liberalised Kerala.

As a commodity that has negotiated with and inhabited different geographical and cultural terrains, the engagements of television in Kerala and its assimilation into the regional sensibilities and "structures of feeling" constitutive of the region suggest the ways in which it has evolved into a representative metaphor symbolising the region's techno-cultural geographies. The attempts to tease out the imbrications of television with the politico-discursive terrains in Kerala become a nuanced endeavour on considering that television is not only an object interlaced within the political economies of the region but also a medium that curates and influences the ideational sites of the region. In such a context, even the act of thinking about television becomes a layered

This Open Access article is published under a Creative Commons Attribution Non-Commercial 4.0 International License (http://creativecommons.org/licenses/by-nc/4.0/), which permits non-commercial re-use, distribution, and reproduction in any medium, provided the original work is properly cited. For citation use the DOI. For commercial re-use, please contact editor@rupkatha.com. 
process that "helps shape the way the media operate within the culture" (Susman, 2003). While television was introduced in India in 1959, Kerala's first encounter with television, Doordarshan per se, occurred only in 1985 following the then Prime Minister Indira Gandhi's decision that the Asian Games held in India shall be telecast all across the country (Santhoshkumar, 2014). During the period under consideration, television was largely a rare and scarce medium, if one is to replicate Robin Jeffrey's (2010) tripartite periodisation into rare, scarce and mass medium, on the basis of the availability of newspapers in Kerala, onto the visual medium of television. During this eventful time, when pre-liberalised Kerala was undergoing rapid social, cultural and economic reconfigurations (which will be discussed in the second section), television became an object that is embedded within the "public discourses of modern capitalism as well as the private discourses of home and household" (Silverstone and Haddon, 1996). The chapter will be divided into two sections. The first section tries to discuss the new temporal dimensions that television inaugurated in pre-liberalised Kerala when television was a rare commodity and Doordarshan was the only channel available. The second section attempts to understand the way in which television embodied and mediated the consumerist aspirations that defined the age. To this end, the paper employs discourse analysis and visual analysis as its primary research methodologies.

\section{Temporalities of television}

The introduction of television in Keralam was part of a larger process of national development, and modernity (Mankekar, 1999). At this point in time, television was considered as an instrument that should aid the process of national 'becoming'. As far as the politico-economic circumstances are concerned, television tried to define a new epoch marked by techno-mediated modes of development. Here, television, as a state-sponsored infotainment platform, functioned as an intermediary site that tried to synchronise the temporal coordinates of uneven modernisation in the country. Through programmes about scientific farming, hygiene, family planning that were telecast through television sets installed in community halls and teleclubs across the country to ensure its greater penetration, television sought to flatten the spatio-temporal differences in an attempt to fashion a new relation with the historical time of the nation.

In addition to redefining the nation's relation with its history, television also structured the everyday life of the viewers. The discourses and practices that crystallised around television would reveal the ways in which the commodity was intimately involved in engendering a sense of time. As various critics have observed, the act of watching television is located within a "milieu of distraction" as it is conceived as a complementary process that accompanies other actions (Spigel, 1992). Some scholars have argued that the flow of the programmes in the television is congruous with the interruptions and banality that distinguish a woman's engagements with the household chores (Modleski, 1983; Browne, 1984). Thus, television-viewing is commonly theorized as an ordinary, and often impalpable, act that could be lost amidst the ubiquity of other habitualized actions. The popular conception of television-viewing as an activity that transpires in the background gains considerable significance in the regional context of Kerala as various articles that appeared in the popular Malayalam magazines of the time anticipated the permeation of television-viewing into the routine actions of the everyday to such an extent that it will no longer 
require the active involvement of the viewer, as in the case of watching television while having family meals (Radhakrishnan, 1988). Similarly, another cautionary narrative that was published in Mathrubhumi warns against the adverse effects of undeterred television-viewing on children (Narendranath, 1992). These accounts situate television-viewing as an act that does not involve the active discernment of the viewer. Here, television was posited as an instrument that facilitates the 'colonization' of time. Such narratives evince a growing preoccupation with the link between television and the active perception of time, articulating suspicion towards television's ability to cloud "time-reckoning" (Munn 96).

The period that saw the introduction of television also witnessed a proliferation of discourses on how time is "spent, wasted, killed, kept, and lost", teasing out the differences between "leisure time, quality time, good times, bad times..." (Aveni, 1989). The reading public was constantly cautioned to be a discerning viewer who is attentive to the consequences of indiscriminate television viewing. Thus, accounts about the deleterious effects of television on children and familial relationships - like addiction to television, tendency among children to imitate the actions seen in television, mismanagement of domestic chores- constantly figured in the popular magazines of the time (Kumar, 1990: Narendranath, 1992). On the other hand, television also sought to engender the modern viewing-citizen through various programmes. As Nancy D. Munn observes in the context of temporal media, control over time indicates "cultural governance through reaching into the body time of persons and coordinating it with values embedded in ... a wider constructed universe of power" (109). By telecasting programmes like Krishidarshan, Yuvadarshan, Arogyavedi etc., television tried to mold the ideal citizen who would aid India's modernisation. While these programmes were meant to introduce the viewers to more efficient methods to manage various resources and to create a common platform where the social and scientific developments of the country will be appreciated, they discreetly initiated new understandings about managing time. These programmes that were telecast during the evening in Malayalam Doordarshan tried to restructure social roles and leisurely pursuits so that time would be utilized more purposively by strategically obliterating the boundaries between personal time and socially beneficial labour. To this end, specific orientation towards time and its disciplined utilization were cultivated among the viewers. Programmes like Veetuvishesham and Sindooram aimed to address the mental and physical health of women even as they tried to develop the employable skills of women. Even a casual act of indulgence in television programmes would instruct the viewer about the ideal way to efficiently manage time as television was largely an infotainment platform at this point in time. Hence, recreation and leisure were effectively redefined in ways that would benefit the society as television-viewing was codified as an instructive entertainment.

Television's ability to organise the social and private life of the viewers becomes evident through the narratives about television which appeared at that time in some popular magazines like Mathrubhumi and Manashasthram. Viewers tried to arrange their daily schedules in such a way that it would align with the screening time of various programmes. As a result, the scheduling of programmes and their temporal contours were capable of effecting spatial reconfigurations as well. An anecdote that appeared in a magazine article titled "Njaayaraazcha Pettiyile Ramayanam" (translated as "Ramayanam in the Sunday Box") shares the story of a grandmother who 
assiduously waits in front of the television for the Ramayan, a religious serial (Thikkodiyan, 1988). As Ramayan, which was telecast at nine in the morning on Sundays, assumed a religious significance among the viewing public, its screen time attained a religious and ritualistic importance, resulting in the transformation of the domestic space into a sacred space. This new "time consciousness" (Glennie and Thrift, 2002), realised through the narrative potentialities embodied by television, enabled the resignification of television-viewing into a social ritual contingent on the temporal axes that allowed the emergence of new social formations and spatial reconfigurations. Thus, the commingling of the technological and the social through the induction of temporally bound television-viewing practices effected changes in the "specific semantic of the everyday" (Bausinger, 1984).

The introduction of television in Kerala witnessed the "reorganizing of the rhythms of everyday life through technical objects" (Charpy, 2017). Television's ability to be discreetly assimilated into the domestic routine also elicited discourses pertaining to the more economical usage of time. While juxtaposing television and newspapers, an article that was published in the popular Malayalam magazine Mathrubhumi opines that television's ability to surmount spatiotemporal differences and its incorporation into the everyday lived reality of the region would facilitate the more efficacious utilization of time (Radhakrishnan, 1988). Since television-viewing presupposes simultaneity of action, whereby it figures in conjunction with other routine domestic chores, it often remains as a discreet practice. As Radhakrishnan (1988) observes in an article in Mathrubhumi magazine, television's ability to disseminate information without disrupting other routine activities like dining and cooking distinguishes it from other media technologies. Similarly, television-viewing figured not only in conjunction with other activities as it also served as an interim activity that engaged the viewer during the interval between domestic chores. While discussing women's employment and social mobility in Kerala, Filippo Osella and Caroline Osella(2000) recall the example of a retired employed woman named Sarasamma who watches television while waiting for the dinner to cook. Thus, television serves as a domesticated commodity that is entwined with other quotidian activities. In this context, television-viewing becomes an exemplar of "time-thrift" (Thompson, 1967), as it often figures as an impalpable act that remains unquantified amidst or occupies the intervening time between other routine actions. Thus, the temporal contours of television-viewing is not only weaved into the structure of everyday but also embodied through other habitualised practices as it serves as reference nodes or temporal qualifiers that mark and circumscribe the time taken by other domestic chores. Here, television-viewing becomes a contingent act that constitutes the rhythm and texture of the complementary activities that occurs along with it.

During this time, television was not a commodity that was affordable by everyone. People used to gather together in a household with a television set to watch various programmes (Chandran, 2014). As a result, television was instrumental in engendering new socialities constituted on the basis of a shared sense of time. By mediating new socialities and viewing rituals, television reconfigured socio-spatial relations. The spatial realignments produced through the viewing publics constituted within the domestic space replicates power dynamics and hegemonic relations in the society. Flippo Osella and Caroline Osella(2000) cite the example of an Ezhava family in Kerala that would only allow their poorer neighbours and relatives to sit only on their 
doorstep while watching television. Hence, the new socio-spatial formations that are formed around the act of television-viewing reflect the social underpinnings and haptic cultures that mediated the activity. The temporal contours of these novel social formations, cohering around television within the private space of the domesticity, were 'timed' and mediated by television. These new viewing communities or socialities also reconfigured the socio-spatial relations in the region as the distinctions between the public space and private space of the domesticity were blurred. As a result, these modern publics which are formed, through shared spaces of sociality, around the act of television-viewing evince that television facilitated various temporally-bound social practices and interactions. Moreover, in the distinct context of Kerala, where a gendered and classed community of viewers gathered together in a single household to watch programmes like Ramayan, Mahabharat, Malayalam news or Malayalam films that were telecast on Sundays (Thikkodiyan, 1988), the temporalities of television enable the convergence of personal time, which decides the viewing-subject's negotiations with the socio-spatial variables around them, and collective time, shared among the immediate community of viewers and the imagined public who are discursively interpellated into existence through the programmes that are aired.

Thus, the introduction of television in Kerala inaugurated new ways of relating to time and created an "ecology of devices" by means of which spaces, communities and discourses are 'timed' (Hutchkins as cited in Glennie and Thrift, 2002). By introducing television into the familiar space of the home, one could observe the reconfiguration of socio-spatial formations, entwining the temporal contours inaugurated through television with the more mundane and habitualised practices of the everyday. Here, television-viewing, an act 'timed' by technological and infrastructural factors as much as by socio-cultural reasons, imbued meanings that were directly contingent on the individual's negotiations with the everyday, and their social identity as part of the immediate circle of viewers who share specific socio-spatial identifiers and the larger national imaginary of citizen-viewers. In such a context, the temporalities signified by television denote new social rituals, and assumes new values based on the duration and location of viewing.

\section{Television and Consumerist aspirations}

The social, economic, cultural and political changes occurring in pre-liberalised Kerala played a pivotal role in the rapid penetration of television across the region. In such a context, the material and symbolic value attributed to television, which mediated its reception in Kerala, ought to be studied. With this aim in mind, this section attempts to study the ways in which television was marketed to its potential buyers through popular magazines in order to understand the culturally anchored strategies that were employed to appeal the social and economic ethos that defined the consumerist aspirations that characterised the period.

At around the time when television was introduced into Kerala, the socio-economic terrains of Kerala witnessed many social developments through various state-sponsored initiatives like land reforms, ensuring education and primary health facilities, more systematic distribution of food grains., etc (Sreekumar and Parayil, 2010). Nevertheless, the "Kerala model of development" also came under harsh criticism for the unstable economic base on which various 
developmental initiatives were premised (Eapen and Kodoth, 2002). While this inevitably affected the economic stability and consumerist practices of the region, the Gulf boom and the large-scale migration to these countries alleviated the impending economic crisis in Kerala (Sreekumar and Parayil, 2010). These socio-economic changes brought forth a new "local cosmopolitanism" in the region (Bose and Varughese, 2015). It is in the context of this vernacular modernity hinged on social development and transnational migration that the marketing strategies employed for selling television and the wide reception that it enjoyed ought to be situated.

In the specific context of Kerala, television becomes a culturally rooted material artifact that denotes socio-economic capital and aesthetic sensibility even as it mediates the sensorial experiences and political outlook. Despite the radical social reformations and the commitment for development that characterised the age, the period also witnessed the emergence of new stratifications which were symbolised by television's role in molding the consumerist aspirations of the region. By analysing how television was advertised to its initial audience, it becomes possible to understand how "the material and the discursive are mutually implicated" (Barad, 2008).

On perusing the popular magazines that were in circulation in and around the time when television was introduced, it becomes evident that it was a highly sought-after commodity. Many electronic companies vied for public attention through their descriptions of the commodity by promising greater quality and clarity of images. By choosing to advertise in the popular magazines like Mathrubhumi, Deshabhumani, Manashastram, Madhyamam, Malayala Manorama, the prominent electronic brand names were trying to sway the literate readers who had the time not only to read these magazines but also to view the programmes being telecast through television. This puts in place some implied assumptions about the aesthetic sensibility and socio-economic status of the potential consumer and viewer of television.

In the advertisement published by Crompton Greaves in the magazine Malayala Manorama (1987), one comes across a television with the image of the cricketer Kapil Dev on its screen (Figure 1). The catchphrase that appears along with the picture of the television screen could be roughly translated as "Two Stars that Perpetually Shine" (translation mine). The choice of Kapil Dev, and cricket, to market television could only be strategic. The popularity of cricket in the Indian subcontinent was escalating as never before from the late 1970s onwards (Ray, 2008). During this time, cricket was "vernacularized" and "indigenized" to such an extent that it became the representative symbol of nationalism in India (Mannathukaren, 2007). In such a context, deploying the celebrity status of Kapil Dev, who was influential in elevating cricket into a sport enjoyed by the masses and appealed the huge fan base of cricket through his simple game plan and family background (Ray, 2008), sought to channelise the mass appeal of cricket and the cricketer to popularise television. Moreover, attempting to market television through the popularity of cricket was especially beneficial as cricket matches were only telecast through television. In this case, television is marketed as a commodity that is consistent with the consumerist aspirations of the region through some nationalist imaginaries anchored on cricket. 
7 Television and Material Culture: Mediating the Temporal and Consumerist Practices in Pre-liberalised Kerala

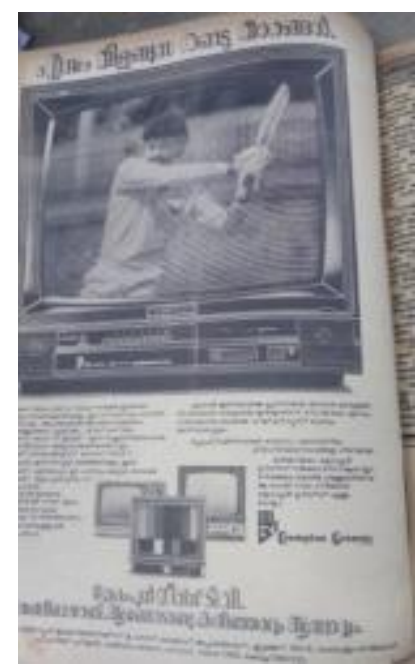

Figure 1

The advertisement by Dianora that appeared in the popular magazine Malayala Manorama (1987), among many other magazines, promises a greater visual experience (Figure 2). In addition to the juxtaposition of a butterfly and television, the caption accompanying the image says that the domestic space will be beautified through the colours unleashed by Dyanora television (translation mine). This reveals the "utilitarian and decorative functions" of television (Leal, 1990). By marketing television as a recreational commodity that could be safely accommodated into the domestic sphere, the advertisement attempts to allay the anxieties about the disruptive potential of television. The attempts to market television as an electronic gadget that is in congruence with the dynamics of the family suggest the discursive construction of the domestic space as a viable site for television. While socio-economic mobility facilitated by the new economic reforms and gulf remittances promoted various consumerist aspirations, it became increasingly impossible to disentangle these impulses from the popular imaginations of ideal domesticity. The subtle attempts to refashion the domestic space through the new consumption practices while guaranteeing its harmony suggest the strategic cultural positioning of television as a nonthreatening presence in the home. This becomes especially relevant while trying to accommodate an object like television into the intimacy of the home as it is the most visible sign of socioeconomically inflected consumption practices. Similar is the case with the advertisement by EC TV in Deshabhimanimagazine (1987) (Figure 3). Here, the image of television is given along with the image of two birds sitting in the moonlight with a caption that could be roughly translated as "Dreams spread their wings through the colours of EC" (Translation mine). By assuring a more vibrant and wholesome domestic experience, the advertisement not only conceives "liveliness [as] intrinsic to the materiality of the thing" (Bennett, 2009) but also implies social recognition through television's presence in the domestic space. These subtle attempts to imaginatively reconstitute the familial sphere so as to ensure the domestication of television suggest that television was primarily marketed as a commodity for domestic consumption. 


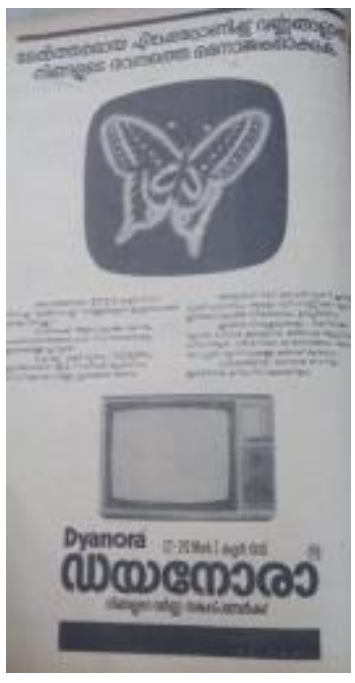

Figure 2

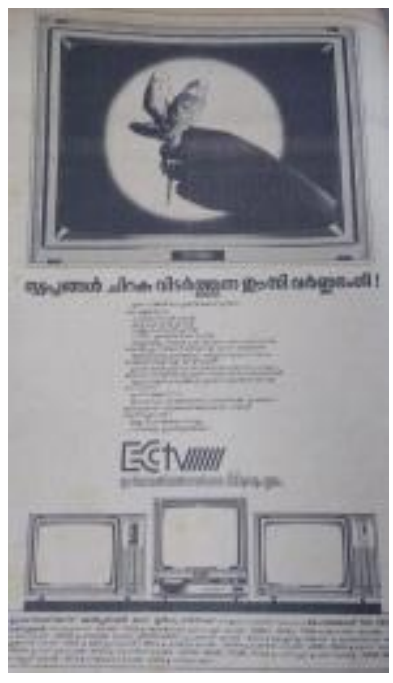

Figure 3

While television was often marketing as a commodity that is congruent with the popular imaginations of ideal domesticity and consumerist aspirations that characterised the region, it was also employed to entice the consumers into buying other material commodities as well. The magazine advertisement that appeared in Malayala Manorama (1987) (Figure 4), which strategically deployed a television-viewing family in order to market Little Genie generators produced by Birla Yamaha, would suggest the ways in which the advertisement hinged on television's status as a domesticated commodity that would buttress the aesthetic appeal of the domesticity while catering to its recreational requirements. The advertisement pits two familiesone with the generator set and the other without- against each to imply that the commodity being advertised would ameliorate the visual experience of watching television. Moreover, the advertisement also banks on the popularity of cricket in the region as it juxtaposes the disappointment of a family as power went out while watching an exciting cricket match with the contentment of another family that has bought the generator. Moreover, the visually appealing and spacious living room with fancy furniture where the family has gathered to watch the cricket match also implies the aesthetic ideals and material aspirations that television mediates. Such images of well-furnished rooms, where happy families actively perform the act of televisionviewing, hint at the modalities through which "aesthetic production has become integrated into commodity production" (Jameson, 1993). The influence of such images in the popular imagination becomes evident as television became a ubiquitous presence even in poor households (Osella and Osella, 2000).

A magazine clipping in Malayala Manorama shows a social event where a television is presented as a gift to the winner of a lucky draw (1987). As objects visibilise "the hierarchies of value" (Grassby, 2005), this incident reveals the economic value ascribed to television as the description to the image suggest that the first prize winner will be awarded either a colour television or domestic appliances worth Rs 10,001. Since television is a commodity that mediates public transactions, it assumes an economic value which is at once social and domestic. Here, social relations and transactions are validated by television as much as these public rituals sanctify and attest the value of television. On emplacing this incident within the larger politico-economic 
conditions that characterised Kerala at that point in time, it becomes possible to deduce that television forges social practices, social relations and consumption practices even as it assumes social and cultural value in the process.

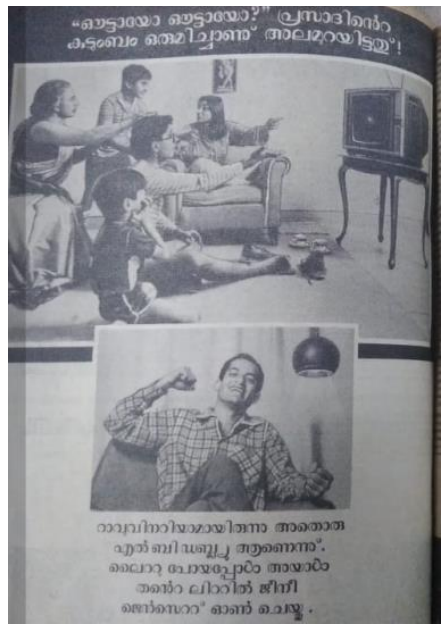

Figure 4

The visual semiotics and discursive strategies employed in the above-mentioned advertisements suggest the ways in which television was projected as a commodity that was ascribed social, economic and cultural value. Its ability to embody various domestic aspirations rooted in social mobility, consumerist practices, changing socio-economic relations indicates that it was intimately connected to the formation of new social identities. By studying television's influence in sculpting the everyday negotiations and consumption practices, one could understand the processes through which it was assimilated into the regional context of Kerala. Thus, the discursive strategies employed to market television as a tamed object and its ability to blend into the banality of habitualised practices suggest that it is at once a commodified material object that inhabits the cultural terrains of Kerala and a cultural artifact that influences the material relations in the region.

\section{References}

Aveni, Anthony. (1989). Empires of Time: Calendars, Clocks and Cultures. Basic Books.

Barad, Karen. (2008). Posthumanist Performativity: Toward an Understanding of how Matter Comes to Matter. In Stacy Alaimo and Susan Hekman (Ed.), Material Feminisms (pp. 120-154). Indiana UP.

Bausinger, Hermann. (1984). Media, Technology and Daily Life. Media, Culture and Society, 6, 343-351. https://doi.org/10.1177/016344378400600403

Bennett, Jane. (2010). Vibrant Matter: A Political Ecology of Things. Duke UP.

Bose, Satheese Chandra and Shiju Sam Varughese. (2015). Introduction- Situating an Unbound Region: Reflections on Kerala Modernity. In Kerala Modernity: Ideas, Spaces and Practices in Transition (pp. 1-24). Orient Black Swan. 
Browne, Nick. (1984). The Political Economy of the Television (super) text. Quaterly Review of Film Studies, 9(3), 174-182. https://dx.doi.org/10.1080/10509208409361210

Chandran, Baiju. (2014). Introduction. In T. K. Santhoshkumar, Malayala Television Charithram: 1985-2013 (pp. 9-30). Kerala Press Academy.

Charpy, Manuel. (2017). How Things Shape Us: Material Culture and Identity in the Industrial Age. In Anne Gerritsen and Giorgio Riello (Eds.), Writing Material Culture History (pp. 199-221). Bloomsbury.

Coltman, Viccy. (2017). Material Culture and the History of Art(efacts). In Anne Gerritsen and Giorgio Riello (Eds.), Writing Material Culture History (pp. 17-31). Bloomsbury.

Eapen, Mridul and Praveena Kodoth. (2002). Family Structure, Women's Education and Work: Reexamining the High Status of Women in Kerala. CDS Working Papers, 341, (pp. 4-50).

Glennie, Paul and Nigel Thrift. (2002). The Spaces of Clock Times. In Patrick Joyce (Ed.), The Social in Question: New Bearings in History and Social Sciences (pp. 151-174). Routledge.

Grassby, Richard. (2005). Material Culture and Cultural History. Journal of Interdisciplinary History, 35(4), 591-603.

Jameson, Frederic. (1993). Postmodernism, or, the Cultural Logic of Late Capitalism. In Thomas Doherty (Ed.), Post-modernism: A Reader (pp. 62-92). Columbia UP.

Jeffrey, Robin. (2010). Media and Modernity: Communication, Women and the State of India. Permanent Black.

Kumar, S. Sajeev. (1990, March 31). Television Nammale Engane Swaadhinickunnu (How does television influence us?). Manashasthram, 155-162.

Leal, Ondina Fachel. (2006). Popular Taste and Erudite Repertoire: The Place and Space of Television in Brazil. Cultural Studies, 4(1), 19-29. https://dx.doi.org/10.1080/09502389000490021

Mankekar, Purnima. (1999). Screening Culture, Viewing Politics: An Ethonography of Television, Womanhood and Nation in Postcolonial India. Duke UP.

Mannathukaren, Nissim. (2007). Reading Cricket fiction in the times of Hindu Nationalism and Farmer Suicides: Fallacies of Textual Interpretation. The International Journal of the History of Sport, 24(9), 1200-1225. https://dx.doi.org/10.1080/09523360701448349

Modleski, Tania. (1983). The Rhythms of Reception: Daytime Television and Women's Work. In E. Ann Kaplan (Ed.), Regarding Television: Critical Approaches- An Anthropology (67-75). The American Film Institute.

Munn, Nancy. (1992). The Cultural Anthropology of Time: A Critical Essay. Annual Review of Anthropology, 21, 93-123. https://www.jstor.org/stable/2155982.

Narendranath, Konniyoor R. (1992, January 19). T. V. Enna Bhayankaran (The Monster named TV). Mathrubhumi, 69(46), 24-25.

Osella, Filippo and Caroline Osella. (2000). Social Mobility in Kerala. Pluto P.

Pavanan. (1988, January 31). Ramayanavum Dooradarshanum (Ramayan and Doordarshan). Mathrubhumi, 65 (47), 16-21.

Radhakrishnan, C. (1988, April 20). Kadalasinte Attiyum TVyude Pettiyum (Paper Stacks and Television Box). Mathrubhumi, 6-9. 
Rajagopal, Arvind. (2004). Politics After Television: Religious Nationalism and the Reshaping of the Indian Public. Cambridge UP.

Ray, Somshankar. (2008). 'The Wood Magic': Cricket in India- A Postcolonial Benediction. The International Journal of the History of Sport, 25(12), 1637-1653. https://doi.org/10.1080/09523360802327483

Santhoshkumar, T. K. (2014). Malayala Television Charithram: 1985- 2013. Kerala P Academy.

Silverstone, Roger and Leslie Haddon. (1996). Design and the domestication of information and communication technologies: technical change and everyday life. In Robin Mansell and Roger Silverstone (Eds.), Communication by Design: The Politics of Information and Communication Technologies (44-74). Oxford UP.

Spigel, Lynn. (1992). Make Room for TV: Television and the Family Ideal in Postwar America. U of Chicago P.

Susman, Warren. (2003). Culture as History: The Transformation of American Society in the Twentieth Century. Pantheon Books.

Sreekumar, T.T. and Govindan Parayil. (2010). Social Space, Civil Society and Transformative Politics of New Social Movements in Kerala. In K. Ravi Raman (Ed.), Development, Democracy and the State: Critiquing the Kerala Model of development (237-250). Routledge.

Thikkodiyan. (1988, January 15). Njayaraazcha Pettiyile Ramayanam (Ramayanam in the Sunday Box). Mathrubhumi, 65(46), 16-17.

Thompson, E.P. (1967). Time, Work discipline and Industrial Capitalism. Past and Present, 38, 56-97.

Benita Acca Benjamin is a PhD Research Scholar in the Institute of English, University of Kerala, India. She completed her Undergraduate course in English Language and Literature from Mahatma Gandhi University and pursued her Postgraduate course in English from Hyderabad Central University, India. She has an MPhil in English from the Institute of English, Kerala University. Her MPhil thesis is titled "Embodied Femininity and Gendered Bodies: An Intersectional Reading of Malayalam Soap Operas". She has presented papers in various National and International Conferences and her research papers have been published in national and international journals. Her areas of interests are Cultural Studies, Media Studies, Gender Studies, and Kerala Modernity. 